\title{
Controlling the end-groups of Poly (3- Hexylthiophene) via Vilsmeier-haack reaction
}

- Lam Le ${ }^{1}$

- Anh Tuan Luu ${ }^{2}$

- Le-Thu Thi Nguyen²

- Ha Tran Nguyen ${ }^{1,2}$

${ }^{1}$ Materials Technology Key Laboratory, VNU-HCM

${ }^{2} \mathrm{Ho}$ Chi Minh City University of Technology - VNU-HCM

(Manuscript Received on October $9^{\text {th }}, 2014$; Manuscript Revised November 19 $9^{\text {th }}, 2014$ )

\begin{abstract}
$\pi$-Conjugated oligomeric and polymeric conformable, and wearable electronics. In this semiconductors have been the focus of intense research over the past few decades as research, we aim at modification of the $\mathrm{H} / \mathrm{Br}$ end alternatives to inorganic semiconductors for lowgroups of poly (3-hexylthiophene) to $\mathrm{CHO} / \mathrm{Br}$ end groups via Vilsmeier-haack reaction using cost electronic applications such as organic thin$\mathrm{POCl}_{3}$ and $\mathrm{DMF}$ as the catalytic system in film transistors (OTFTs), light-emitting diodes toluene medium. The end groups of the obtained (OLEDs), and photovoltaics (OPVs). These polymer were determined via FT-IR spectroscopy materials enable vapor- or solution-phase fabrication of large-area, lightweight electronic and were further confirmed by Maldi-ToF. The result showed that completion of the Vilsmeierdevices and are compatible with plastic haack reaction was obtained after 24 hat $75^{\circ} \mathrm{C}$. substrates for mechanically flexible,
\end{abstract}

Keywords: Poly (3-hexylthiophene), GRIM, Conjugated Polymers, Maldi-Tof spectroscopy.

\section{INTRODUCTION}

Polythiophenes have become the subject of extensive study. These materials are viewed as potentially useful components in field-effect transistors, optical and electronic sensors, lightemitting devices, non-linear optical materials, etc $[1,4]$.

\section{Trang 40}




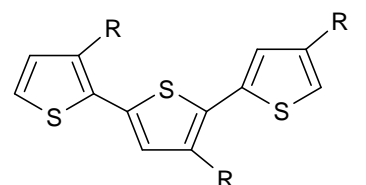

HT - HT

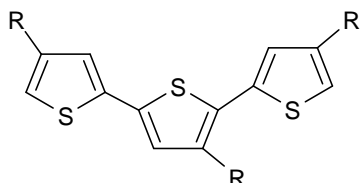

T T - HT

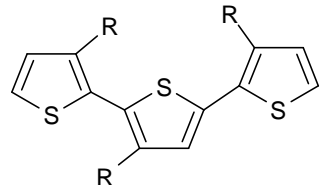

$\mathrm{HH}-\mathrm{HT}$

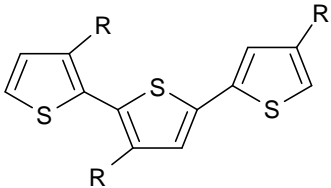

$\mathrm{HH}-\mathrm{TT}$
However, these polymers exhibit an intrinsic insolubility which makes purification, as well as chemical modification and processability, difficult. To overcome this major inconvenience, the introduction of long alkyl chains in the $\beta$ position of the thiophene ring has been envisaged. In fact, the poly(3-alkylthiophenes) P3AT shows a very good solubility in common organic solvents. However, the alkyl substituent in a thiophene ring can be incorporated into a polymer with different regioregularities head-to-tail (HT), tail-to-tail (TT) and head-to-head (HH) [5-7].

Recent research on P3AT has focused on the HT regioregularity. Indeed, these HT regiospecific polymers have improved electroconductivity, optical nonlinearity and magnetic properties over regiorandom polymers in which more sterically hindered $\mathrm{HH}$ linkages can cause defects in the conjugated polymer chains and reduce the desired physical properties of the materials.

Therefore, in this study, we aim to modify the end groups of P3HT via Vilsmeier-Haack reaction using $\mathrm{POCl}_{3}$ and DMF as the catalytic system. The end-groups of P3HT were characterized via FTIR and Maldi-Tof spectroscopies.

\section{EXPERIMENT}

\subsection{Materials}

3-Hexyl thiophene, N-bromosuccinimide, iodine, iodobenzendiacetate were purchased from Acros and used as received. $\mathrm{Ni}$ (dppp) $\mathrm{Cl}_{2}$, i$\mathrm{PrMgCl}$ in tetrahydrofuran (THF) $(2 \mathrm{~mol} / \mathrm{l})$ were also purchased from Acros and stored in glove box at room temperature. 2-Bromoisobutyryl bromide (Br-iBuBr), triethylamine ( $\left.\mathrm{NEt}_{3}, \quad 99 \%\right)$, 1,1,4,7,10,10-hexamethyltriethylenetetramine (HMTETA, 97\%), N,N-dimethylformamide anhydrous (DMF, 99.8\%), sodium borohydride $\left(\mathrm{NaBH}_{4}, 99 \%\right)$ and phosphorus(V)oxychloride $\left(\mathrm{POCl}_{3}, 99 \%\right)$ were purchased from Aldrich. Copper(I) bromide $(\mathrm{CuBr}, 98 \%)$ was purchased from Fluka and used without further purification. Chloroform $\left(\mathrm{CHCl}_{3}\right.$, Labscan, 99\%), toluene (Labscan, 99\%), tetrahydrofuran (THF, Labscan 99\%) were dried using an MBraun solvent purification system under $\mathrm{N}_{2}$. Dichloromethane (Chem-Laboratory, 99.8\%), n-heptane (Labscan, 99\%), n-hexane (Labscan, 99\%) and methanol (Chem-Laboratory, 99.8\%) were used as received. All reactions were performed in oven-dried glassware under purified nitrogen.

\subsection{Characterization}

Attenuated total reflection Fourier transform infrared (ATR FT-IR) spectra were recorded using BIO-RAD Excalibur spectrometer equipped with an ATR Harrick Split PeaTM. Size exclusion chromatography (SEC) of $\mathrm{P} 3 \mathrm{HT}$ was performed in THF (sample concentration: $1 \mathrm{wt} \%$ ) at $35{ }^{\circ} \mathrm{C}$ using a polymer laboratories (PL) liquid chromatograph equipped with a PL-DG802 degazer, an isocratic HPLC pump LC1120 (flow rate: $1 \mathrm{ml} / \mathrm{min}$ ), a Basic-Marathon Autosampler, a PL-RI refractive index detector and three columns: a guard column PL gel $10 \mu \mathrm{m}$ and two columns PL gel mixed-B $10 \mu \mathrm{m}$. Molecular 
weight and molecular weight distribution were calculated with reference to polystyrene standards. Data were acquired in continuum mode until acceptable averaged data were obtained. MALDI mass spectra were recorded using a Waters QToF Premier mass spectrometer equipped with a nitrogen laser, operating at 337 $\mathrm{nm}$ with a maximum output of $500 \mathrm{~mW}$ delivered to the sample in $4 \mathrm{~ns}$ pulses at $20 \mathrm{~Hz}$ repeating rate. Time-of-flight mass analyses were performed in the reflectron mode at a resolution of about 10,000. All the samples were analyzed using trans-2-[3-(4-tertbutylphenyl)-2-methylprop-2enylidene]-malononitrile (DCTB), that matrix was prepared as $20 \mathrm{mg} / \mathrm{mL}$ solution in $\mathrm{CH}_{2} \mathrm{Cl}_{2}$. The matrix solution $(1 \mathrm{lL})$ was applied to a stainless steel target and air dried. Polymer samples were dissolved in $\mathrm{CH}_{2} \mathrm{Cl}_{2}$ to obtain $1 \mathrm{mg} / \mathrm{mL}$ solutions. $1 \mathrm{lL}$ aliquots of those solutions were applied onto the target area already bearing the matrix crystals, and air-dried. For the recording of the single-stage MS spectra, the quadrupole (rf-only mode) was set to pass ions from 750 to $3000 \mathrm{Th}$, and all ions were transmitted into the pusher region of the time-offlight analyzer where they were mass analyzed with $1 \mathrm{~s}$ integration time

\subsection{Preparation of P3HT with controlled end- groups}

Into the flask under nitrogen atmosphere containing 2-bromo-3-hexyl-5-iodothiophene $(2,36 \mathrm{~g}, 6,31 \mathrm{mmol})$ was added dry THF $(30.0 \mathrm{~mL})$ via a syringe, and the mixture was stirred at $0^{\circ} \mathrm{C}$. i- $\mathrm{PrMgCl}$ (2.0 M solution in THF, 3,16 mL, 6,31 mmol) was added via a syringe, and the mixture was stirred at $0^{\circ} \mathrm{C}$ for $0.5 \mathrm{~h}$. A suspension of $\mathrm{Ni}$ (dppp) $\mathrm{Cl}_{2}$ (72 mg, $\left.0.13 \mathrm{mmol}\right)$ in THF (10.0 mL) was added to the mixture via a syringe at $0^{\circ} \mathrm{C}$, and then the mixture was stirred at room temperature. After the reaction mixture was stirred for 1 day, the $\mathrm{HCl}$ aqueous solution $5 \mathrm{~N}$ was added drop by drop. The mixture was stirred for another $0.5 \mathrm{~h}$ and then precipitated in cold $\mathrm{MeOH}$. The product was washed well with $\mathrm{MeOH}$ to afford a purple solid, $>98.5 \%$ rr-HT-P3HT (1,2 g, 72\%, $\mathrm{M}_{\mathrm{n}}=7606$, PDI $=1.12)$.

\subsection{Optimization of Vilsmeier-Haack reaction}

H-P3HT-Br $\left(\mathrm{M}_{\mathrm{n}}=4061, \mathrm{PDI}=1.24\right)(300 \mathrm{mg}$, $0.074 \mathrm{mmol}$ ) was dissolved in anhydrous toluene $(80 \mathrm{~mL})$ under $\mathrm{N}_{2}$. N,N-Dimethylformamide (1 $\mathrm{mL}, 13 \mathrm{mmol})$ and $\mathrm{POCl}_{3}(0.7 \mathrm{~mL}, 7.6 \mathrm{mmol})$ were added. The reaction was carried out first at $75{ }^{\circ} \mathrm{C}$ for $3 \mathrm{~h}$. The solution was cooled to room temperature, followed by the addition of saturated aqueous solution of sodium acetate. The solution was stirred for another $2 \mathrm{~h}$. The polymer was precipitated in cold methanol and washed well with water, then methanol.

\section{RESULTS AND DISCUSSION}

A formyl-de-hydrogenation of the as-obtained $\alpha$-bromo P3HT (Br-P3HT-H) protic end-group was successfully performed by Vilsmeier reaction (second step). The evolution of the reaction was followed by MALDI-ToF analysis until complete transformation of the $\alpha$-bromo P3HT (Scheme 1) to $\alpha$-bromo, $\omega$-formyl P3HT (Scheme 1). The mechanism of the Vilsmeier-Haack reaction can be described as in Scheme 1.

\section{Trang 42}




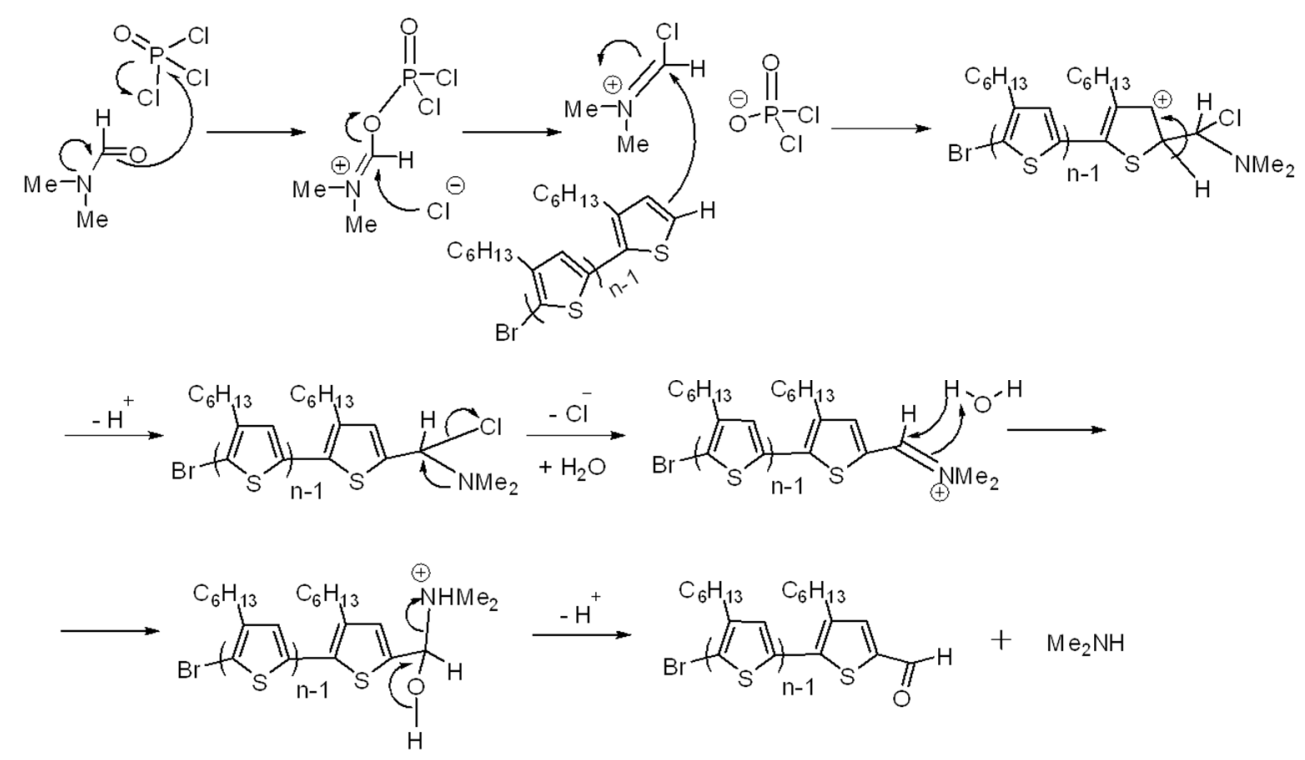

Scheme 1. Vilsmeier-Haack mechanism for formyl-de-hydrogenation of P3HT.

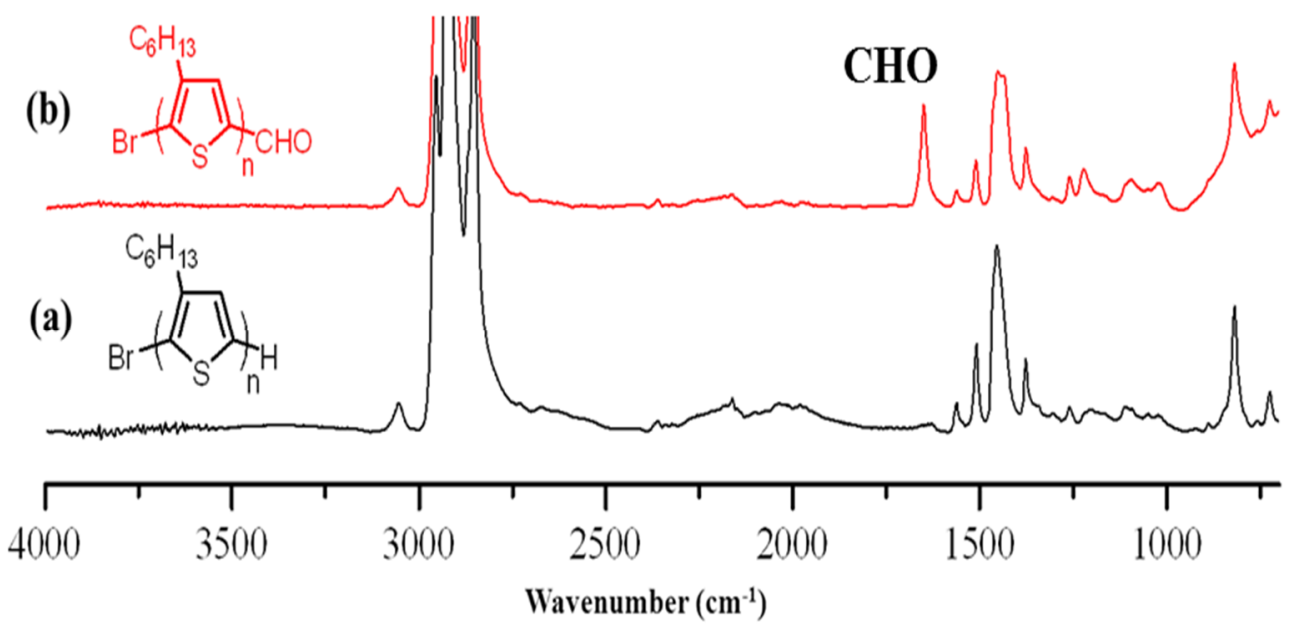

Figure 1. FT-IR spectra of (a) Br-P3HT-H, (b) Br-P3HT-CHO

The FT-IR spectroscopy in Figure 1 shows the characteristic peak at $1650 \mathrm{~cm}^{-1}$ attributed to the $\mathrm{CHO}$ groups of P3HT.

The MALDI-ToF result of $\alpha$-bromo, $\omega$-formyl is presented in Figure 2. The results showed that the end-groups may be controlled with the $\mathrm{HCl}$ addition rate. To confirm this observation, two P3HT samples, with the same $M_{n}\left(D_{p}=30\right)$, were synthesized with different quenching rates. With a fast quenching, only $\mathrm{H} / \mathrm{Br}$ end-groups were obtained (Figure 2, above), whereas with a slow quenching, a mixture of $\mathrm{H} / \mathrm{Br}$ and $\mathrm{Br} / \mathrm{Br}$ endgroups was obtained (Figure 2, below). 


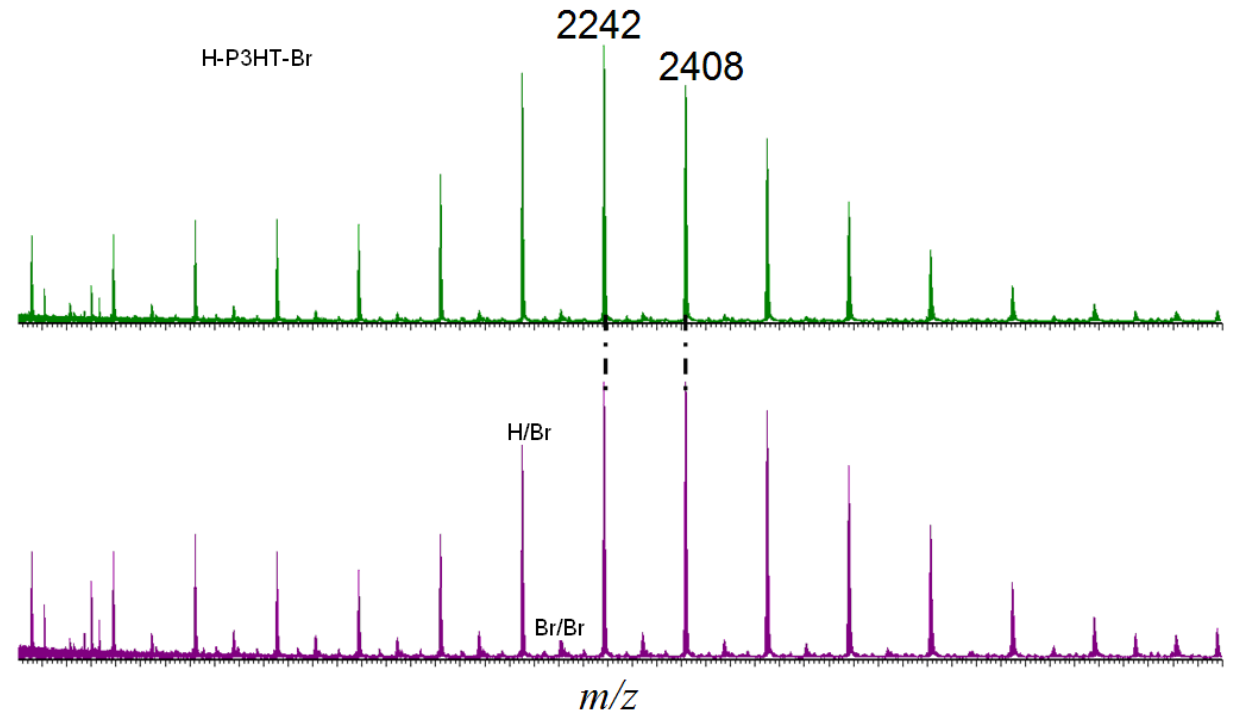

Figure 2. $\mathrm{P} 3 \mathrm{HT}$ with $\mathrm{HCl}$ fast addition (above), $\mathrm{HCl}$ slow addition (below)

MALDI-ToF analysis showed that the $\mathrm{H}-$ the Vislmeier reaction until finding the optimal $\mathrm{P} 3 \mathrm{HT}-\mathrm{Br}$ was partially transformed into $\mathrm{CHO}-$ reaction time (that ensures the completion of the $\mathrm{P} 3 \mathrm{HT}-\mathrm{Br}$. This product was re-used to carry out end group modification).
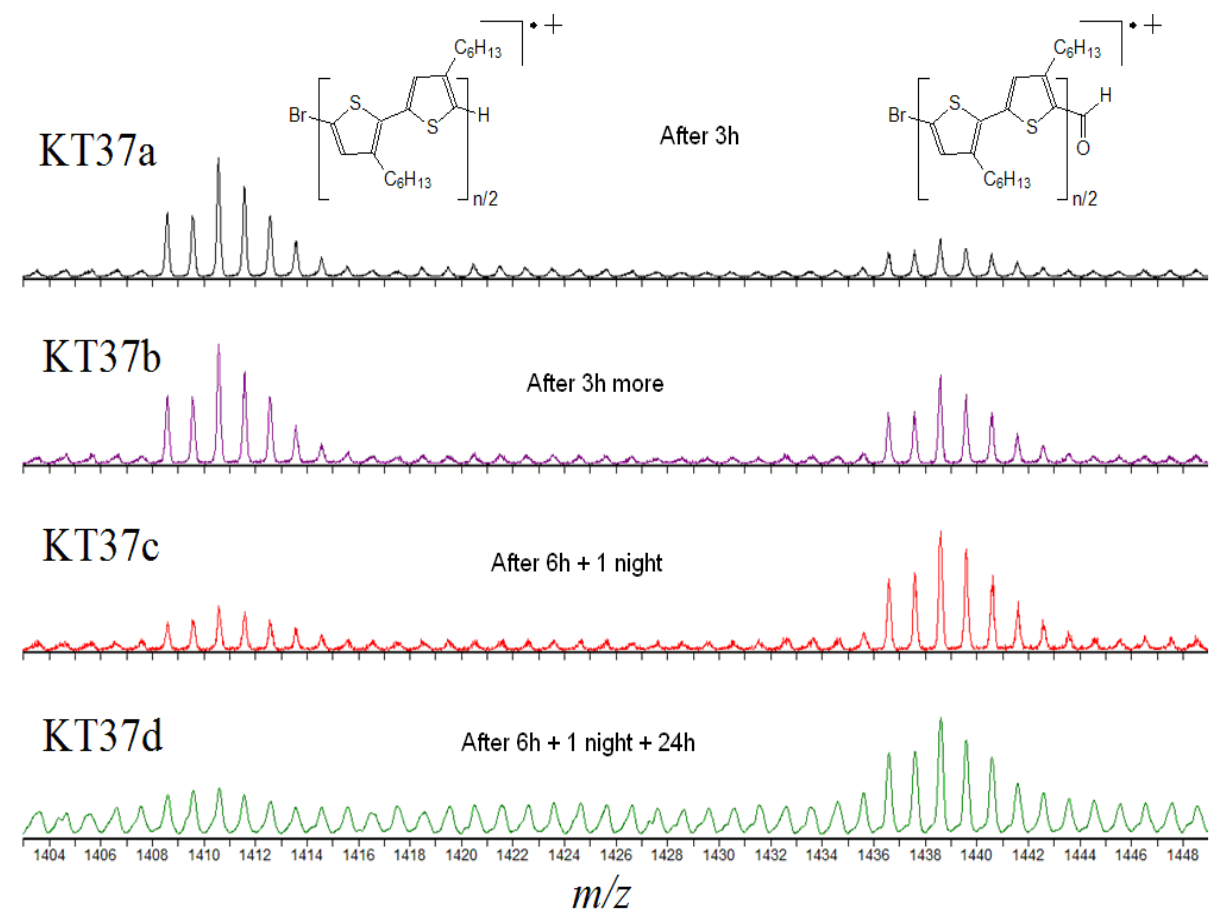

Figure 3. Evolution of Vilsmeier reaction. 


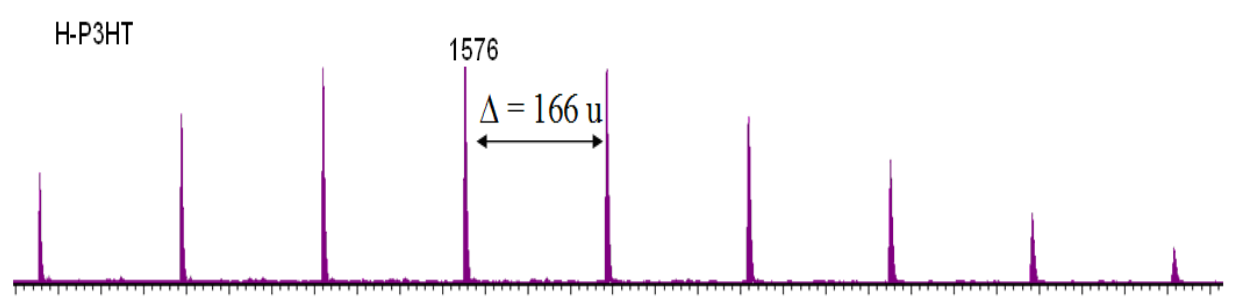

$1604(1576+28)$

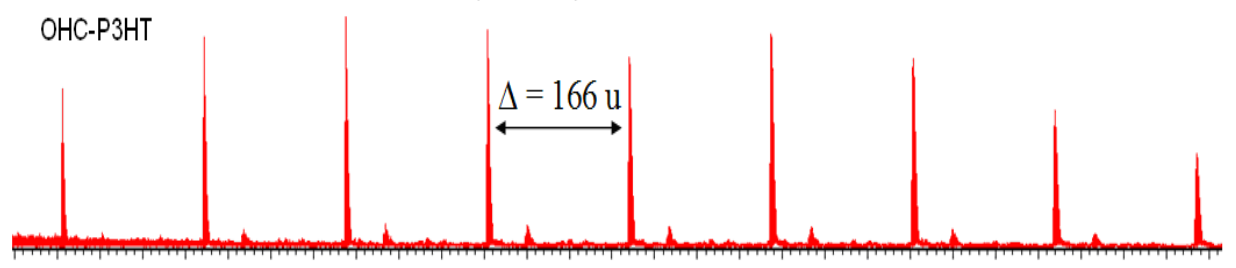

Figure 4. Before (above) and after (below) Vislmeier-Haack reaction.

As seen in Figure 3, the $\omega-\mathrm{H}$ end group was totally transformed into $\omega$-CHO end group after almost 48h. Therefore, the Vislmeier reaction was carried out in $24 \mathrm{~h}$ and the $\mathrm{DMF} / \mathrm{POCl}_{3}$ quantity was doubled. In fact, with this condition, another H-P3HT-Br $\quad\left(\mathrm{M}_{\mathrm{n}}=3481\right.$, PDI=1.24 $)$ was totally transformed into CHO-P3HT-Br (Mn=3504, PDI=1.23) with 94\% yield (Figure 4).

\section{Conclusion}

The end-groups of P3HT were successfully transferred from $\mathrm{H} / \mathrm{Br}$ to $\mathrm{CHO} / \mathrm{Br}$ via VislmeierHaack reaction. The end groups of P3HT were determined via FT-IR and MALDI-ToF spectroscopies. The comparison of the MALDI$\mathrm{ToF}$ traces manifested the end-group change of the starting Br-P3HT-H to Br-P3HT-CHO after completion of the Vilsmeier-Haack reaction ( $24 \mathrm{~h}$, $\left.75^{\circ} \mathrm{C}\right)$.

Acknowledgement: This research was supported by the project "T-CNVL-2014-05" from Ho Chi Minh City University of Technology - Vietnam National University - Ho Chi Minh City, 268 Ly Thuong Kiet, District 10, Ho Chi Minh City, VietNam and was supported by Vietnam National Foundation for Science and Technology Development (NAFOSTED) under grant number "104.02-2013.18". 


\section{Điều khiển nhóm cuối mạch của Poly (3- Hexylthiophene) bằng phản ứng Vilsmeier- haack}

- Lê Lâm ${ }^{1}$

- Lưu Tuấn Anh ${ }^{2}$

- Nguyễn Thị Lệ Thu²

- Nguyễn Trần Hà ${ }^{1,2}$

1PTN Trọng Điểm ĐHQG-Công Nghệ Vật Liệu

${ }^{2}$ Trường Đại học Bách khoa, ĐHQG-HCM_nguyentranha@hcmut.edu.vn

(Bài nhận ngày 13 tháng 10 năm 2014, hoàn chỉnh sủa chũa ngày 15 tháng 12 năm 2014)

\section{TÓM TẮT}

Các oligomer và polymer cấu trúc mạch liên hợp đã được nhắm đến cho nhũng nghiên cưu manh mẽ qua nhũ̃ng thập kỷ vùa qua nhur là sự lưa chọn thay thế cho các bán dẫn vô co vì mang lại lợi ich về giá thành rẻ trong nhũng ứng dụng linh kiện điện tử nhu là bán dẫn hũu co, phát quang OLED và pin năng lương mặt trời hũu co: Nhũng loại vật liệu này có thể gia công bằng phuoong pháp bay hoi hoặc phuoong pháp tráng phủ dung môi. Nhũng phuơng pháp này sẽ cho phép quy trình gia công trên một diện tích lơnn. Bên cạnh đó, các sản phẩm điện tử nền hũu cơ sẽ có trọng luợng nhẹ, mềm dẻo thuận tiện cho việc di chuyển của người sủ dụng. Trong nghiên cưu này, chúng tôi nhắm đến việc biến tính nhóm chưc cuối mạch $\mathrm{H} / \mathrm{Br}$ của polymer poly(3hexylthiophene) thành nhóm $\mathrm{CHO} / \mathrm{Br}$ bằng phản úng Vilsmeier-haack sủ dụng hệ xúc tác $\mathrm{POCl}_{3}$ và DMF trong dung môi toluene. Nhóm chức cuối mach của polymer thu được được phân tích qua phổ hồng ngoại FT-IR và được xác định lại bằng phuơng pháp phổ khối Maldi-ToF. Kết quả biến tính nhóm chức cuối mạch bằng phản úng Vilsmeier-haack cho thấy rằng để đạt được hiệu quả chuyển hóa hoàn toàn, phản ứng Vilsmeierhaack cần phải thực hiện trong 24 giờ tại nhiệt độ $75^{\circ} \mathrm{C}$.

Keywords: Poly(3-hexylthiophene), GRIM, Conjugated Polymers, Maldi-Tof spectroscopy.

\section{REFERENCES}

[1]. Patil, A.O.; Heeger, A.J.; Wudl, F. Chem. Rev. 1988, 88, 183.

[2]. Roncali, J. Chem. Rev. 1992, 92, 711; McCullough, R.D.
[3]. McCullough, R.D.; Ewbank, P.C. In Handbook of conducting polymers, $2^{\text {nd }}$ ed.

[4]. Skotheim, T.A., Elsenbaumer, R.L., Eds, Marcel Dekker: New York, 1998, p 225.

\section{Trang 46}


[5]. Babel, A.; Jenekhe, S. A. Synth. Met. 2005, 148, 169.

[6]. Al Ibrahim, M.; Roth, H. K.; Schroedner, M.; Kalvin, A.; Zhokhavets, U.; Gobsch, G.;
Scharff, P.; Sensfuss, S. Org. Electron. 2005, 6, 65 .

[7]. Ahn, T.; Choi, B.; Ahn, S. N.; Han, S. N.; Lee, H. Synth. Met. 2001, 117, 219. 